\title{
Enhanced cooperation in practice. An analysis of differentiated integration in EU secondary law
}

\author{
Daniela A. Kroll and Dirk Leuffen
}

\begin{abstract}
The article offers a first comprehensive overview of the workings of enhanced cooperation in the European Union (EU). Although this form of second ary law differentiation exists since the Amsterdam Treaty, it has only rarely been used so far. In the article, we formulate a theory of when and why enhanced cooperation is used in EU decision making. Our theory builds on rationalist institutionalism focussing on institutions, preference constellations and the externality structure of policies. We test the plausibility of our theoretical claims by combining comparative and within case analyses of nine cases. The empirical findings underline that the usage of enhanced cooperation depends to large degrees on the externality structure of the goods under consideration. The article ends with a short normative evaluation of the enhanced cooperation procedure.
\end{abstract}

KEY WORDS Decision making; differentiated integration; enhanced cooperation; public goods theory

\section{INTRODUCTION}

This article analyses the usage of enhanced cooperation $(\mathrm{EnC})$ in the European Union (EU). Established by the Treaty of Amsterdam, this instrument of differentiated integration has been modified in subsequent Treaty reforms. Today EnC allows a closer co-operation between a subgroup of at least nine member states in the realm of EU secondary law. However, the procedure has only rarely been used so far. Accordingly, most accounts of EnC remain rather formalistic, as they do not analyse the procedure in practice. We depart from this, first by formulating a theory about the usage and the consequences of $\mathrm{EnC}$, and then by tentatively testing this theory, combining comparative and within-case analyses. Based on rational institutionalist premises, our theory further develops and partly simplifies ideas prominently introduced to the study of (differentiated) integration by Kölliker (2001), Genschel and Plümper (1997) and Mattli (1999). We argue that the usage of EnC depends on a set of institutional conditions as well as constellations of actor preferences. Furthermore, the externality structure of the goods under consideration has strong impacts on the dynamics and outcomes of the decision-making 
process by setting different incentives for the supporters and opponents of a policy. Neutral external effects make it comparatively easy to establish EnC. In case of positive or negative external effects, i.e., effects on the non-participants, the establishment of EnC depends on the cost and benefit structures of the drivers and laggards. The empirical application of our theory to nine cases underlines that our theoretical model can be considered as a baseline theory for studying EU decision-making in the context of EnC. While we do find partial deviations from our theoretical expectations, the causal process tracing reveals that these deviations are mostly idiosyncratic. In the concluding part of the article we summarize our findings and provide a brief normative assessment of EnC.

\section{CONSTITUTIONALIZING FLEXIBILITY: EnC IN THE EU}

Although EnC has been constitutionalized at Amsterdam and reformed under each subsequent treaty, it has only been used since the Lisbon Treaty entered into force. The Treaty clauses are commonly divided into general and pillarspecific provisions (e.g., Peers 2010, Philippart and Edwards 1999). While the former defines its objectives and scope ( $c f$. Title IV Art. 20 TEU), the latter set the procedural conditions for its authorization and implementation ( $c f$. Title III Art. 326-334 TFEU). As EnC has neither been used nor seriously considered in Common Foreign and Security Policy (CFSP), we focus on the provisions for the other policy areas ( $c f$. Cremona [2009] for the rules on CFSP).

$\mathrm{EnC}$ can be divided into three stages: initiation; authorization; and implementation. At the initiation stage at least nine member states, as a measure of 'last resort', submit their requests of $\mathrm{EnC}$ to the Commission, which will either issue a proposal for authorizing $\mathrm{EnC}$ or inform the interested member states of its reasons for not doing so. The Council then decides on authorizing EnC by qualified majority voting (QMV), having obtained the consent of the European Parliament (EP). After the authorization decision the Commission submits an implementing proposal on which only the participating member states vote in the Council. The speed of decision-making can be increased at this stage. According to the passerelle clauses the EnC group in the Council can unanimously change decision-making from unanimity to QMV and/or from a special to the ordinary legislative procedure ( $c f$. Art. 333 TFEU). According to Article $20 \mathrm{TEU}, \mathrm{EnC}$ 'shall aim to further the objectives of the Union, protect its interests and reinforce its integration process. Such co-operation shall be open at any time to all Member States.'

\section{A THEORY OF WHEN AND HOW EnC IS USED IN THE EU}

The establishment of the EnC procedure extends the choice set of legislative outcomes in the EU. In principle, we can distinguish four types of outcomes that vary along two dimensions. The first dimension relates to the number of participating member states and can be dichotomized into the categories of 
uniform and differentiated participation. Under uniform participation all EU member states have the same rights and obligations concerning a specific policy. In differentiated participation, the territorial extension of membership and rule validity is incongruent (cf. Holzinger and Schimmelfennig 2012). The second dimension refers to the legislative status quo of the EU: is it altered or not? The following types result:

(1) status quo for all member states;

(2) uniform integration (with all member states adopting a new piece of EU legislation);

(3) $\mathrm{EnC}$;

(4) 'outside cooperation' (a subgroup of member states establishes closer ties between themselves on the basis of international law, but outside the EU's legal framework).

We now need to ask why and when EnC should be selected over the alternatives. First, the legal grounds must exist. Second, there must be some degree of heterogeneity of member state preferences. If all member states agree on an issue, either uniform or no integration at the level of the status quo should result. For EnC to occur, we need a relatively homogenous subgroup of member states driving the integration process to face opposition from more hesitant member states. Third, the unanimity criterion makes EnC more likely. EnC is an instrument to overcome gridlock and under unanimity the likelihood of gridlock rises, ceteris paribus (Tsebelis 2002). At the same time EnC could also, in principle, apply in a policy falling under QMV (for example, when the QMV threshold is above the EnC threshold).

Simply based on these conditions, we could expect a frequent usage of $\mathrm{EnC}$ in the EU. In reality, however, there are very few instances where EnC has been used. How can we explain this discrepancy? While sociological institutionalists like Lewis (2010) might refer to the normative environment of the EU that in principle favours unity instead of differentiation between the member states, we develop a rationalist explanation of why unity is often preserved - either on the level of the legislative status quo or on the level of deeper integration. Following Kölliker (2001), we argue that the type of good and, more directly, the externality structure of the good under consideration should determine whether EnC is likely to result from the interactions of member states. We expect that the externality structure of a good influences the behaviour of both the drivers and the laggards of integration, albeit in different manners. In the following we assume the drivers to desire more integration, in principle; either in the form of complete integration or EnC. The laggards are assumed to favour, in principle, the status quo over deeper integration. The perceived externality structure (i.e., the effects on non-participants) in turn should determine whether the laggards prefer $\mathrm{EnC}$ (with them being outsiders) over the status quo or uniform integration. If an issue is perceived to entail neutral external effects, the laggards should not object to the drivers proceeding with EnC, since they are not negatively affected by the others moving forward. Likewise, under such conditions, 
the drivers have clear incentives to proceed with EnC. The situation changes, however, if $\mathrm{EnC}$ is expected to entail negative external effects for the outsiders. While the drivers, as above, should remain in favour, the laggards should be opposed to establishing EnC. They should thus try to prevent this procedure; if they fail and $\mathrm{EnC}$ is established despite their opposition, the outsiders should ultimately join the drivers in order to avoid these negative externalities (provided the costs of the negative externalities are higher than those of participation). In contrast, in case of positive external effects, the outsiders should favour the establishment of EnC. However, positive externalities should also reduce the readiness to provide this public good in the first place (Olson 1965). Only if the benefits of co-operation are greater for the drivers than the expected costs of free-riding do we expect EnC to occur. As Kölliker (2001), but also Genschel and Plümper (1997), show, the costs and benefits can also differ according to the ratio of participants and outsiders.

Our theoretical expectations are summarized in the following hypotheses (since the presence of preference heterogeneity and legal grounds are necessary conditions of $\mathrm{EnC}$, they are not again listed here):

$\mathrm{H} 1: \quad \mathrm{EnC}$ is more likely to be used in policies that demand unanimity rather than qualified majority voting.

$\mathrm{H} 2$ : If a policy entails neutral external effects, EnC is likely to occur.

$\mathrm{H} 3$ : If a policy entails negative external effects, the outsiders should try to stop the establishment of EnC.

$\mathrm{H} 3.1$ : If the laggards successfully prevent EnC, the status quo prevails.

$\mathrm{H} 3.2$ : If the laggards cannot stop $\mathrm{EnC}$, they are likely to join the drivers over time.

H4: $\quad$ In case of positive external effects, EnC should occur if its benefits outweigh the costs imposed on the drivers by free-riding. If the costs are higher, the drivers should offer side payments or concessions to the laggards. If they fail to 'convince' the opposition by such means, the status quo prevails.

So far, we have neglected one type of outcome, namely 'outside cooperation'. Outside cooperation can be an option if there is no legal basis either for establishing EnC or for generally allowing the $\mathrm{EU}$ to become active in a policy area. An example from primary law is the establishment of the Schengen border regime, where the EU lacked the 'constitutional' foundations for abolishing the border controls amongst the member states in the 1980s ( $c f$. Leuffen $e t$ al. 2013). In addition, one could expect that outside cooperation is used by member state governments trying to circumvent or minimize the supranational institutions' impact on legislation.

\section{A CASE STUDY DESIGN}

Because there are comparatively few cases of EnC, we cannot provide rigorous quantitative tests of our hypotheses. We instead opted for a case study approach, 
combining qualitative within-case analyses with systematic cross-case comparisons. In order to avoid selection bias, we not just include 'positive' cases of EnC into our analysis, but also cases where the usage of $\mathrm{EnC}$ was seriously envisaged at some point of the decision-making process. This strategy follows Goertz's (2006) 'possibility principle'. The 'negative' cases were detected through keyword searches of primary and secondary literature on differentiated integration. In total, we identified nine cases that we included into our study. Fortunately, the outcomes of these cases span across all four categories of outcomes distinguished above. So far, only three cases have reached the implementation stage of EnC, namely the law applicable to divorce and legal separation, the European patent, and the (at the time of writing) still negotiated Financial Transaction Tax (FTT). In three cases, namely the Common Consolidated Corporate Tax Base (CCCTB), the framework decision on certain procedural rights in criminal proceedings (FCCP) and the European Public Prosecutor's Office (EPPO), no further integration was reached, maintaining the status quo. In the cases of the European arrest warrant (EAW) and the European company statute (ECS), uniform integration was established. Finally, in one case, Prüm, outside cooperation resulted.

To identify the main issues of conflict and the positions of member states during the negotiations we analysed official EU documents (especially Council minutes) and secondary literature. The qualitative approach allows us to control for a range of different variables in our process-tracing of the individual cases (we will introduce the relevant control variables in the empirical analysis). The empirical part of this article is structured in a slightly unorthodox way, since we start by first presenting the results of the cross-case comparison before turning to the individual case studies. The reason for choosing this format is that owing to space constraints we are very limited in presenting the results of our process tracing. In addition, we want to avoid that the reader getting lost in too many details at the start. We therefore first present our general conclusions based on the comparison of our nine case studies. We then address the mechanisms and explain the empirical deviations from our theoretical expectations in more detail. To highlight the mechanisms and dynamics of EnC we particularly emphasize the 'positive cases' where EnC actually occurred in practice.

\section{RESULTS}

In the following we first present the findings of our cross-case comparison before turning to the results of the causal process tracing. As expected, for all cases (including Prüm) the necessary treaty provisions existed and, indeed, member states disagreed over the ideal outcomes of the decision-making process. Furthermore, all our cases related to policy areas for which the treaties, in line with hypothesis 1 , foresaw unanimity.

Table 1 summarizes the findings relating to the 'external effects' variable. This variable captures whether a policy of EnC would entail neutral, positive or 
Table 1 Case study results

\begin{tabular}{lllc}
\hline & & \multicolumn{2}{c}{ Variable } \\
\cline { 2 - 4 } Case & External effects & Outcome & Overall fit \\
\hline Rome III & Neutral & EnC & + \\
European patent & Negative & EnC & + \\
FTT & Aut.: positive; & EnC & Aut.: + \\
& Impl.: negative & & Impl.: + \\
CCCTB & Positive & SQ & + \\
EPPO & Positive & SQ & + \\
FCCP & Neutral & SQ/UI & + \\
ECS & Negative & UI & $+/-$ \\
EAW & Neutral & UI & $+/-$ \\
Prum & Neutral & OC & - \\
\hline
\end{tabular}

Notes: $+=$ confirmation; $-=$ non-confirmation; FTT = Financial Transaction Tax; CCCTB $=$ Common Consolidated Corporate Tax Base; EPPO = European Public Prosecutor's Office; FCCP = Framework decision on certain procedural rights in criminal proceedings; ECS = European company statute; EAW = European arrest warrant; $\mathrm{EnC}=$ Enhanced cooperation; $\mathrm{SQ}=$ status quo; $\mathrm{UI}=$ uniform integration; $\mathrm{OC}=$ outside cooperation; Aut. = authorization; Impl. = implementation.

negative external effects for those member states that are not part of the EnC group. In five of our nine cases, the 'external effects' variable correctly predicts the outcome (being a result of the interactions between drivers and laggards). In particular, the cases of Rome III, the European patent, the FTT, the CCCTB and the EPPO confirm our theoretical predictions. In the case of the FCCP the necessary condition of reaching a large enough number of drivers for EnC is not met. For the ECS and the EAW our findings are mixed. Only in the case of Prüm are our predictions not in line with the expected outcome. For those cases that at first sight seem to disconfirm our theory, process tracing reveals that idiosyncratic variables are largely responsible for the accounted deviations. We argue that such variables cannot systematically be included into a parsimonious theoretical model applicable to small- or medium- $\mathrm{N}$ samples. Thus, overall the process-tracing analyses largely support our theoretical expectations.

\section{Law applicable to divorce and legal separation}

The first case where EnC was successfully established concerned the law applicable to divorce and legal separation, also referred to as 'Rome III' (Kuipers 2012). According to the European Commission 13 per cent of the 122 million marriages in the European Union are 'international'. In 2007, 140.000 (again 13 per cent) of all divorces in the 27 member states had an 
'international' element (European Commission 2010a) 104 final), which means that spouses possessed different nationalities, lived apart in different countries or in a member state other than their country of origin. Without a unified EU approach each country applies its own conflict-of-law rules, which according to the Commission creates legal uncertainty and unpredictability. Against this backdrop, the Commission had adopted a proposal on applicable law in matrimonial matters already in 2006 (European Commission 2006). After two years of negotiation, the Council acknowledged that insurmountable differences prevented passing the proposed regulation (the legal basis prescribed unanimity). The Council established 'that the objectives of the proposed Regulation could not be attained within a reasonable period by applying the relevant provisions of the Treaties' (Council of the EU; 1 June 2010, Interinstitutional File: 2010/0066 (APP)). According to the Commission, one member state (which was most probably Sweden) 'did not consider it appropriate that its courts should apply foreign divorce law, which it regards as more restrictive than its own divorce law, and wished to continue applying its own substantive law to any divorce requested in its courts (lex fori approach)'. (Note that the United Kingdom [UK], Ireland and Denmark would not have been bound to the regulation; while Denmark has a general opt-out, the UK and Ireland have the possibility to opt-in to legislation under Title IV TFEU).

In response to this gridlock, 13 member states formally requested EnC in the area of divorce law. The aim of establishing EnC was not to substantively harmonize domestic divorce and legal separation laws. Instead, it should provide a 'clear and comprehensive legal framework in the area of divorce and legal separation in the participating Member States and ensure adequate solutions for citizens in terms of legal certainty, predictability and flexibility and prevent a 'rush to court' (Council of the EU; 1 June 2010, Interinstitutional File: 2010/0066 (APP)). In particular, it introduces harmonized conflict-of-law rules to matrimonial proceedings. This should enable spouses to easily predict which law will apply. In addition, the regulation would introduce flexibility and a limited autonomy granting the spouses to choose the applicable law. This would be particularly useful in cases of divorce by mutual consent. In March 2010 the Commission launched the establishment and implementation of $\mathrm{EnC}$ in divorce and legal separation matters ( $c f$. European Commission 2010a, 2010b). After having received the European Parliament's approval without amendment, 23 member states authorized EnC on 12 July 2010. Denmark, Poland and Sweden abstained. Finland abstained and published a formal statement in which it deplored a lack of flexibility in the negotiations. On 20 December 2013 all participating states voted in favour of the implementation regulation that had slightly been amended by the European Parliament in its first reading ( $c f$. Peers 2010).

The law applicable to divorce and legal separation clearly mirrors our theoretical expectations. During the negotiations tensions emerged between more liberal states such as Sweden and more conservative states like Malta ( $c f$. Boele-Woelki 2008). The drivers of EnC, with the exception of Malta and 
Latvia, all previously applied divorce law according to a (varying) scale of factors. They thus form a relatively homogeneous subgroup, being able to agree on a harmonized conflict-of-law rule. Most opposition derived from states that followed a lex fori approach. In the end, however, the non-participants included liberal Scandinavian states but also catholic Ireland or Poland. In contrast, Malta managed to negotiate some safeguard clauses that allowed its participation in EnC (cf. Boele-Woelki 2011, Kuipers 2012). In its declaration of 5 July 2010, Finland 'regrets that the EnC is about to be launched for the first time in the field of family law which is closely connected with fundamental values and traditions of Member States' (Council of the EU; 9 July 2010, Interinstitutional File: 2010/0066 (NLE)). Some countries were opposed to the idea that their courts had to apply less restrictive foreign divorce laws. In the Commission's consultations with stakeholders, the concern was expressed that the obligation to apply foreign law might lead to delays and additional costs in matrimonial proceedings ( $c f$. European Commission 2010a). In economic terms, the Commission estimated that the 'notional costs of problems relating to international marriages in divorce situations could total up to EUR 205 million in the EU' (ibid.). However, Henderson (2010), Fiorini (2008) and Kuipers (2012) point out that the link between civil judicial co-operation and economic integration is unclear and that opposition is more closely connected to 'non-economical' values and law tradition.

As already stated above, the unanimity criterion is present in the case ( $c f$. Article 61(c) and 67(1) TEC). But while the regulation as such was contested between the member states, the establishment of EnC did not cause major controversies. In the case of the divorce law the externalities are neutral. In fact, we can consider Rome III as an excludable network good with high excludability and a complementary level of consumption that imposes few costs on outsiders. For the Council:

[e]nhanced cooperation in the area of the law applicable to divorce and legal separation respects the competences, rights and obligations of those Member States that do not participate in it. The common conflict-of-law rules in the participating Member States do not affect the rules of the non-participating Member States. The courts of the non-participating Member States continue to apply their existing domestic conflict-of-law rules to determine the law applicable to divorce or legal separation. (Council of the EU; 1 June 2010, Interinstitutional File: 2010/0066 (APP))

And, indeed, apart from the normative critique formulated by Finland, we find rather little opposition against EnC. This is in line with the expectations formulated in hypothesis 2 . Based on our theory, we do not expect strong centripetal effects to work in this area. Lithuania's later decision to join the group, in our view, cannot be explained through the externality structure, but should rather be attributed to domestic developments. Overall, the case broadly conforms to our theoretical expectations. 


\section{European patent}

Patents are legal titles granting rights to inventors in exchange for their readiness to disclose their inventions. Most economists agree that patents contribute to enhancing innovation, competition and growth by protecting investments into research and development. Patent systems thus contribute to channelling market dynamics in today's knowledge-based economies ( $c f$. Guellec and Van Pottelsberghe De La Potterie 2007). Not surprisingly, the issue has been on the European agenda for a long time. However, the current European patent system was founded outside the European Community. In 1973 the European Patent Convention was signed by 16 European states. The Convention established the European Patent Organization (EPO) and the European Patent Office as its executive arm. Today, 40 states are members of the EPO, including all EU member states. The European Patent Office grants European patents; however, these need to be validated in the countries in which the patent should apply. Since the procedures of validation and the fees differ across countries, the EPO does not offer a truly unified European patent.

In 2007, the European Commission published a communication on 'enhancing the patent system' in Europe, in which it detailed that European patents are about nine times more expensive than Japanese or United States (US) patents. In 2009, the Council reached agreement on establishing a European patent with unitary effect. However, a dispute emerged about the language regime. While a majority of 25 member states agreed to English, French and German as the official languages of the EU patent, Italy and Spain disagreed. Since no compromise was reached on the translation arrangement, 25 member states, after having received the consent of the Commission and the European Parliament, voted in favour of authorizing EnC. Italy and Spain voted against it. In June 2011 these countries submitted formal complaints before the Court of Justice $(\mathrm{CoJ})$, which, however, dismissed their actions in April 2013. In December 2012 the 25 states participating in EnC passed regulations 1257/2012 on a European patent and 1260/2012 on the accompanying language regime.

In the case of the European patent the legal grounds for EnC existed. While Spain and Italy were in principle in favour of establishing a European Patent with unified effect, they claimed that the language regime was discriminatory. In addition, they rejected the use of $\mathrm{EnC}$ in this particular case, arguing that the condition of 'last resort' was not met owing to their general support of a unitary patent. The unanimity criterion was present; while the EU patent itself falls under QMV, the accompanying language measures - in fact, the issues are inseparable - demanded unanimity. The EU patent can be considered an excludable network good because it is possible to exclude outsiders from profiting from the regime. At the same time its consumption is complementary; thus, there is no rivalry emerging from additional consumers. But does the EU patent entail negative external effects? For Italy and Spain the language regime remains discriminatory. In its complaint to the CoJ, Spain argued that EnC would infringe Article 326 TFEU by undermining 'the internal market or 
[the] economic, social and territorial cohesion, constituting discrimination in trade between Member States and distorting competition between them' (Case C-274/11; OJEU C 219/12). For Italy EnC 'adversely affects the single market, introducing a barrier to trade between Member States and discrimination between undertakings, causing distortion of competition' (Case C-295/11; OJEU C 232/21). In their view 'creating uniform protection for innovation in one part only of the Union would encourage activities relating to innovatory products to be drawn to that part of the Union, to the detriment of the non-participating Member States' ( $c f$. Judgement of the Court, 16 April 2013). Moreover, EnC would:

reduce the mobility of researchers from Member States not taking part in this co-operation or from Member States whose official language is not English, French or German, for the language arrangements provided for by the decision will make access to information on the scope of the patents difficult for those researchers. (ibid.)

While the critique of Italy and Spain is not shared by the CoJ, the complaints underline that the two laggards fear negative external effects. Their decision to go to court is in line with the predictions formulated in hypothesis 3. However, so far these countries have not joined the $\mathrm{EnC}$ regime as expected by hypothesis 3.2. Yet, since the ruling of the Court only dates from April 2013, it might be too early to finally reject this hypothesis. All in all, the case of the European patent confirms our theoretical expectations. In particular, its externality structure can account for the observation that the European patent was more controversial than 'Rome III'.

\section{Financial Transaction Tax}

In September 2011, the Commission proposed a harmonized minimum tax rate for all trading activities in the financial market if at least one of the financial institutions is based in a EU member state ( $c f$. European Commission 2011b). The FTT would levy a tax of 0.1 per cent on shares and bonds and of 0.01 per cent on derivatives. Though all member states supported a FTT at the global level (European Council 2010), they were divided to introduce it solely in the EU. Since unanimity, as required by Article 113 TFEU, was not reached, 11 countries requested EnC. In January 2013, the Council adopted EnC ( $c f$. European Commission 2012) by QMV with Malta, Luxembourg, the Czech Republic and the UK abstaining. The implementing proposal (cf. European Commission 2013b) is still being negotiated.

The analysis of this case needs to be disaggregated into the authorization and implementation stage. The authorization proposal, at first, seemed to entail positive externalities by allowing financial actors to evade the FTT by relocating their capital to outsiders' financial markets. At the same time, the drivers were motivated by potential tax revenues from the FTT. According to the Commission the total revenues for the 11 member states are around $€ 34$ billion, which 
is approximately 0.4 per cent of their gross domestic product (GDP) (cf. European Commission 2013a) 28 final). (Note, however, that economists disagree on whether the FTT is beneficial [e.g., Mccullock and Pacillo 2011] or detrimental [e.g., Grahl and Lysandrou 2014; Rogoff 2011] to the market). At the same time, the FTT's political benefits are uncontroversial. Being a symbol of 'social justice' (Heinrich 2013) in the context of the financial crisis, it was widely supported by EU citizens (Eurobarometer 78). Thus, at the authorization stage, the outsiders had good reasons not to oppose the establishment of EnC. Political incentives assured that the drivers were not weighed down by the positive externalities granted to the outsiders. In addition, to reduce the risk of tax evasion the 'issuance principle' was added in the implementing proposal (European Commission 2013a); imposing the FTT even when the financial institutions are outside the FTT-zone, but are trading a financial instrument that was issued within it (cf. European Commission 2013b). Given that this could potentially diminish the attractiveness of outsider's financial markets vis-à-vis non-EU countries, the perceived external effects changed from positive to negative. As theorized, the outsiders, therefore, at this step tried to stop the implementation of the FTT. In April 2013 the UK issued a formal complaint against the authorization of EnC. In its view, implementing the FTT 'will inevitably cause costs to be incurred by the Non-Participating States' ( $c f$. Case C-209/13; OJEU C 171/23). Owing to its 'extraterritorial effects' the FTT would not respect outsiders' competences and rights and be contrary to customary international law. This argument was supported by the Council's legal service (Council of the EU; 6 September 2013, Interinstitutional File: 2013/0045 (CNS)). The lawyers criticized particularly the differential treatment of transactions between two participating member states against transactions involving an insider and an outsider, since the participating state would receive the FTT in the latter case twice. The findings on the FTT are thus broadly in line with our theoretical expectations.

\section{Common Consolidated Corporate Tax Base}

The CCCTB would allow companies operating in at least two EU member states to compute their group taxable income according to a common set of rules. It aims to tackle the problems of over- and double-taxation and the additional compliance costs companies face when engaging in crossborder activities in the Union's internal market ( $c f$. European Commission 2011a). Although debated since the 1960s, the issue remains contested ( $c f$. Article 115 TFEU requires unanimity). While the Commission has suggested to use EnC already in 2004 (Non-Paper to informal Ecofin Council, 10 and 11 September), member states have not formally requested the procedure so far. Their reluctance can be explained by outsiders' positive externalities. In general, tax savings are common pool resource problems (i.e., they are nonexcludable but rival in consumption). Since companies can relocate their capital into countries offering lower tax rates 'at least all potential tax 
havens' have to participate in the co-ordination of these so-called 'weakestlink' goods (Holzinger 2005: 488; emphasis original). In the long term, tax competition might even lead to a 'race to the bottom' between drivers and outsiders (ibid.: 476). Fearing higher costs incurred to their domestic companies, low-tax countries such as the UK and Ireland have been heavily opposed to the CCCTB (Gomes De Andrade 2005). On the other hand, high-tax countries, such as Germany and France, in principle supported it (ibid.). But because EnC is a suboptimal outcome being 'unable to tackle the profit shifting issue' (Schratzenstaller 2007: 119) and generating lower benefits (Brochner et al. 2007), the drivers prefer the status quo. Thus, our theoretical expectations are corroborated by this case.

\section{European Public Prosecutor's Office}

Discussions to create a EPPO that would combat criminal offences affecting the EU's financial interests date back to the mid-1990s ( $c f$. Hamran and Szabova 2013; Wade 2013). Despite broad consensus on the shortcomings of the existing system and the efficiency gains created by a EPPO (Bubrowski 2013), the status quo has been maintained so far (Article 86 TFEU requires unanimity). In the EU, only national authorities can bring perpetrators to court. Although the Union bodies have continuously argued for an EPPO and Lisbon provides for EnC as a 'second step' to achieve it (Klip 2012; White 2013), EnC has not yet been requested. While national parliaments of 11 member states have triggered the yellow card (i.e., Cyprus, the Czech Republic, France, Hungary, Ireland, Malta, the Netherlands, Romania, Slovenia, Sweden and the UK), the creation of an EPPO has been supported by 17 countries. Hence, the minimum number of drivers for $\mathrm{EnC}$ was met. Moreover, several parliaments (i.e., Germany, Poland, Portugal and Romania) alongside the French and German ministers of justice expressed their support (European Commission 2013c). In line with our theory, the non-use of EnC can, however, be explained by positive externalities. In public good terms the EPPO is a non-excludable network good. The level of consumption is complementary, since a higher number of participating states increases the detection rate of frauds. At the same time, outsiders cannot be excluded from the benefits of a better protection of the Union's financial interests. Instead they might gain competitive advantages over the drivers. As Klip (2012) and Wade (2013) argue, the detection of fraud may be contrary to member states' economic interests, if, for example, companies illegally obtained subsidies from the EU. Under EnC the drivers would be the only ones bearing the risk. Similarly, the German Bundesrat (2013) argued that an EPPO is only beneficial if all member states participate. Moreover, EnC might create conflicts on the EPPO's jurisdiction if suspects from both participating and non-participating states are involved (Hamran and Szabova 2013). While concerns about practical feasibility thus also play a role, public goods theory can overall provide a satisfactory understanding of the case. 


\section{Framework decision on certain procedural rights in criminal}

\section{proceedings throughout the European Union}

In April 2004, the Commission proposed to set common minimum standards in five areas of criminal law proceedings (cf. $\operatorname{COM}(2004) 328$ final). Despite intense discussions throughout 2006 and 2007, a consensus was not found. In particular, conflict arose on the type of the legal instrument (Council of Ministers 2006) and the scope of the FCCP; with six countries arguing for its restriction to cross-border cases (Council of Ministers 2007). According to the UK, Ireland, Malta, Slovakia, the Czech Republic and Cyprus, the European Convention on Human Rights renders further EU action unnecessary (Jimeno-Bulnes 2008; Spronken and De Vocht 2011; Wagner 2011). The Commission, supported mostly by France, 'expressed its readiness to consider submitting a proposal for an enhanced cooperation' (Council of the EU; 13 September 2007, Interinstitutional File: Draft Minutes 10699/07). Although the unanimity criterion is present in the case ( $c f$. Article $31 \mathrm{TEU}$ ) and outsiders' externalities are neutral, EnC has not been used. Instead the Council agreed to pursue a step-by-step approach ( $c f$. European Union 2009) and some of the measures have been adopted by all member states in the meantime (i.e., Directive 2010/64/EU, OJEU L 280/1; Directive 2012/13/EU, OJEU L 142/1; Directive 2013/48/ EU, OJEU L 294/1 [European Union 2010, 2012, 2013]). Nevertheless, the status quo partially persists. It seems that support for establishing EnC was very limited. During discussions at the Committee of the Permanent Representatives of the Governments of the Member States to the European Union (COREPER) ' $[s]$ everal delegations noted that, although in principle they were not against using enhanced cooperation, the file procedural rights was not an appropriate file for this legislative procedure [EnC]' (Council of the EU; 5 June 2007, Interinstitutional File: Note from Presidency to COREPER/Council 10287/07). The Presidency noted that EnC was 'at least provisionally, rejected by a blocking minority' (ibid.). Hence, the proposal lacked support and we should not expect enhanced cooperation to occur.

\section{European Company Statute}

In October 2001, the Council adopted the Statute for a European company that had been on the agenda since the 1970s ( $c f$. European Commission 1970). The idea was to give companies that operate in various EU member states the opportunity to form a 'Societas Europae', subject to one set of Union-wide company rules. The ECS proposal consisted of two inseparable issues that had to be adopted by unanimity ( $c f$. Article 208 TEC). While the regulation on the Statute (2157/2001) proved to be uncontroversial, the supplementing directive (2001/86/EC) on employees' involvement created tensions. The opposition from countries with dualistic corporate governance (e.g., Germany, Austria) and countries with lower statutory rights (e.g., the UK, Spain) at the end was largely dissolved by a flexible approach; the Nice European Council offered 
Spain an 'opt-out' (Gold and Schwimbersky 2008; Keller 2002). This outcome is surprising in light of our theory. We had expected Spain to join a potential EnC regime, since the ECS entailed negative externalities. Firms of participating states could profit from cost efficiencies, a simplified corporate legal structure and increased opportunities for cross-border restructuring ( $c f$. Gold and Schwimbersky 2008). This should negatively affect the competitiveness of the outsiders - in this case Spanish companies. Given the centripetal forces put forward in hypothesis 3.2, we would not have expected the drivers to grant concessions to Spain. In our view, this discrepancy can possibly be explained by a general preference for including a maximum number of countries in integration endeavours; an explanation not yet part of our theory. As it stands, Spain, with only minor exceptions, largely participates in the current regime. Furthermore, the Spanish position was also strengthened by the fact that other countries such as the UK supported demands for exceptions from the standard rules of employee representation (Cressey 2009; Gold and Schwimbersky 2008).

\section{European arrest warrant}

The European arrest warrant, adopted in June 2002 (cf. European Union 2002), replaced the classic extradition procedures between EU executives with a system of surrender between national judicial authorities. Tensions emerged on the scope of the EAW. More precisely, Italy demanded a reduced list of offences for which the double criminality would not be checked (Friedrichs 2006; Marin 2008). As Nice prescribed unanimity for legislation on judicial co-operation in criminal matters, Italy's veto blocked the adoption of the EAW (Marin 2008). In response, the EP pleaded for using EnC if 'unanimity [could] only be attained by substantially weakening the proposal' ( $c f$. European Parliament resolution; C 153 E/284 OJEC [European Parliament 2001]). However, consensus for establishing uniform integration was reached in the European Council. In this case, Italy conceded after having come under intense pressure by other member states and the Commission. Commissioner Vitorino complained 'we cannot be held hostage to Council unanimity' and suggested that the 'Council might try to proceed without Italy by using the option of enhanced cooperation to allow the 14 member states to go ahead' (Occhipinti 2003: 171). In addition, Italy was strongly criticized by domestic media (Kaunert 2007). Hence, opting out would have entailed high domestic reputation costs for the government that was accused of acting according to Berlusconi's personal interests (Croci 2002; Friedrichs 2006; Occhipinti 2003; Willan 2001). These pressures seem to have contributed to a shift in the Italian government's position; there is no evidence of side payments being issued by the EU partner states. But the shift of positions makes the interpretation of the case somewhat delicate. Arguably, had Italy stuck to its position, $\mathrm{EnC}$ would have been established, as expected by our theory. The other states' readiness to move forward might have increased the domestic pressures for the Italian government (counterfactually speaking, we would not have imagined a position shift, had Italy 
found more international supporters for its position). Slightly stretching the concept, one could thus argue that $\mathrm{EnC}$ would have created political negative externalities for the Berlusconi government, thereby driving Italy towards cooperation.

\section{The Prüm Convention}

Signed in 2005 between seven member states, the Prüm Convention aims to improve cross-border security co-operation through increased information exchange. Based on the externality structure - Prüm entails neutral external effects - we would have expected EnC to occur. Instead, Prüm was signed outside the Union's legal framework; in the meantime, parts of it were integrated into the acquis. How can this outcome be explained? Officially, the signatories argued that $\mathrm{EnC}$ was not used because of the insufficient number of participants. Yet, since several states (e.g., Finland, Slovenia) joined the initiative shortly afterwards and discussions were primarily held outside the EU, Amtenbrink and Kochenov (2009) argue that the participating countries did not actively seek more partners to avoid the strict conditions of the EnC procedure (see also Král [2008] and Kuipers [2012]). Instead, rapid decisionmaking was preferred to intense negotiations with national parliaments and EU institutions (for a criticism, see Walsch [2008]). Since Prüm was a counterproposal to the Commission's principle of availability (Balzacq and Hadfield 2012; Kietz and Maurer, 2006), outside cooperation allowed the signatories to realize their own preferences rather than seek compromise with other member states under the control of the EU bodies (Kietz and Maurer 2006).

\section{CONCLUSION}

This article analysed how the $\mathrm{EnC}$ procedure plays out in practice. Although established in the 1990s, EnC has only been used since 2010. Its rare use, however, should not be equated with EnC having no impact. In fact, we were able to identify several cases where $\mathrm{EnC}$ was considered at some point of the decision-making process. In addition, $\mathrm{EnC}$ can be used to promote uniform integration, as the analysis of the EAW shows. Furthermore, after Pandora's Box has been opened, we expect the procedure to play an increasingly important role in the future (given that preference heterogeneity should be a common feature in an EU of $28+\mathrm{X}$ ); and, indeed, we find that it has increasingly been used in recent years. In the article we formulate a parsimonious theory for capturing key mechanisms and dynamics of the $\mathrm{EnC}$ procedure. Additional variables relating, for instance, to domestic politics, the salience of issues and the ratio of drivers and laggards should be elaborated in more detail by future research. However, given the limited number of empirical cases, our theory represents a starting point for further investigating the dynamics of EnC. While our theory cannot account for the outcomes of all cases, we still find that it offers a useful tool for dissecting complex processes of (differentiated) integration. In 
general, our analysis shows that the usage of the instrument depends on the content of an issue, and it thus mirrors Lowi's dictum that 'policies determine politics' (Lowi 1972: 299; emphasis original). In particular, the externality structure of the goods under consideration impacts on the behaviour of drivers and laggards. In the case of positive externalities, the usage of the procedure is less likely because the outsiders can free-ride. In the case of negative externalities, the drivers have incentives to use $\mathrm{EnC}$ as a threat to 'discipline' integration laggards (cf. Hanf 2001; Jaeger 2002). This is problematic from a democratic theory perspective, since countries that normally would object to a policy under unanimity are pressured to accept integration. However, EnC also allows the drivers not to be slowed down by the laggards; from such a view, $\mathrm{EnC}$ is a useful technique to accommodate diversity. Our case studies in addition show that $\mathrm{EnC}$ is not always used by the same group or only the larger member states, a fear that was initially expressed by its opponents ( $c f$. Sepos 2005). All in all, the study of EnC can shed some important lights on both differentiation in secondary law and on the functioning and workings of EU decision-making more generally.

Biographical notes: Daniela A. Kroll is a research assistant and Ph.D. candidate in Politics and Public Administration at the University of Konstanz, Germany. Dirk Leuffen Professor of Political Science/International Politics at the University of Konstanz, Germany.

Addresses for correspondence: Daniela A. Kroll, University of Konstanz, Department of Politics and Public Administration, Universitätsstraße 10, Box 83, D - 78467 Konstanz, Germany. email: daniela.kroll@uni-konstanz.de / Dirk Leuffen, University of Konstanz, Department of Politics and Public Administration, Universitätsstraße 10, Box 83, D - 78467 Konstanz, Germany. email: dirk.leuffen@uni-konstanz.de

\section{ACKNOWLEDGMENTS}

Previous versions of this article were presented at the Europakolloquium of the Institute of European Global Studies in Basel 2013, ECSA Norway Annual Conference in Oslo 2014, and the EISS 2014 in Kristiansand. In addition, the authors would like to thank Frank Schimmelfennig and the two anonymous reviewers for their valuable comments.

\section{REFERENCES}

Amtenbrink, F. and Kochenov, D. (2009) 'Towards a more flexible approach to enhanced cooperation?', in A. Ott and E. Vos (eds), Fifty Years of European Integration, The Hague: T.M.C. Asser Press, pp. 181200.

Balzacq, T. and Hadfield, A. (2012) 'Differentiation and trust: Prüm and the insti tutional design of EU internal security', Cooperation and Conflict 47: 53961. 
Boele Woelki, K. (2008) 'To be, or not to be: enhanced cooperation in international divorce law within the European Union', Victoria University of Wellington Law Review 39: 77992.

Boele Woelki, K. (2011) 'For better or for worse: the Europeanization of international divorce law', in A. Bonomi and G.P. Romano (eds), Yearbook of Private International Law, Munich: Sellier European Law Publisher, pp. 1741.

Brochner, J., Jensen, J., Svensson, P. and Sorensen, P.B. (2007) 'The dilemmas of tax coordination in the enlarged European Union', Cesifo Economic Studies 53: 56195.

Bubrowski, H. (2013) 'Ein Raum der Verfolgung. Einwände gegen Entwicklungen in der justitiellen Zusammenarbeit innerhalb der EU', Frankfurter Allgemeine Zeitung, 07 October.

Bundesrat (2013) 'Empfehlungen der Ausschüsse zu Punkt ... der 915. Sitzung des Bundes rates am 11. Oktober 2013. Vorschlag über eine Verordnung des Rates über die Errichtung der Europäischen Staatsanwaltschaft COM(2013) 534 final; Ratsdok. 12558/13', Drucksache 631/1/13, 30 September, Cologne: Bundesanzeiger Vertriebsge sellschaft, available at http://www.bundesrat.de/SharedDocs/drucksachen/2013/0601 0700/631 1 13.pdf\%3F blob\%3DpublicationFile\%26v\%3D3+\&cd=2\&hl=de\& $\mathrm{ct}=\mathrm{clnk} \& \mathrm{gl}=\mathrm{de}$ (accessed August 2014).

Cremona, M. (2009) 'Enhanced cooperation and the Common Foreign and Security and Defence Policies of the EU', Working Paper Law 2009/21, Florence: European University Institute.

Cressey, P. (2009) 'Employee participation', in M. Gold (ed.), Employment Policy in the European Union: Origins Themes and Prospects, London: Palgrave, pp. 13959.

Croci, O. (2002) 'The Second Berlusconi government and foreign policy', The International Spectator 37: 89101.

Council of Ministers (2006) 'Press Release. 2768th Council Meeting Justice and Home Affairs Brussels, 45 December 2006', $15801 / 06$ (Presse 341), Brussels: Council of the European Union, available at http://europa.eu/rapid/press release PRES 06 341 en.htm?locale=en (accessed August 2014).

Council of Ministers (2007) 'Press Release 2807th Council Meeting Justice and Home Affairs Luxembourg, 1213 June 2007’, $10267 / 07$ (Presse 125), Brussels: Council of the European Union, available at http://www.consilium.europa.eu/press/press releases/latest press releases/newsroomloaddocument?id=\&lang=en\&directory=en/ jha/ \&fileName=94682.pdf (accessed August 2014).

European Commission (1970) 'Proposal for a Council Regulation Embodying A Statute for the European Company', COM(1970) 600 final, 30 June, Brussels: Com mission of the European Communities, available at http://eur lex.europa.eu/legal content/EN/ALL/?uri=CELEX:51970PC0600 (accessed August 2014).

European Commission (2004) 'Proposal for a Council Framework Decision on certain procedural rights in criminal proceedings throughout the European Union', COM(2004) 328 final, 28 April, Brussels: Commission of the European Commu nities, available at http://eur lex.europa.eu/legal content/EN/ALL/?uri= CELEX:52004PC0328 (accessed August 2014).

European Commission (2006) 'Proposal for a Council Regulation amending Regu lation (EC) No 2201/2003 as regards jurisdiction and introducing rules concerning applicable law in matrimonial matters', COM(2006) 399 final, 17 July, Brussels: Commission of the European Communities, available at http://eur lex.europa.eu/ legal content/EN/ALL/?uri=CELEX:52006PC0399 (accessed August 2014).

European Commission (2010a) 'Proposal for a Council Decision No.../2010/EU authorising enhanced cooperation in the area of law applicable to divorce and legal separation', $\operatorname{COM(2010)} 104$ final, 24 March, Brussels: European Commission, avail able at http://eur lex.europa.eu/legal content/EN/ALL/?uri=CELEX:52010PC0104 (accessed August 2014). 
European Commission (2010b) 'Proposal for a Council Regulation (EU) implementing enhanced cooperation in the area of the law applicable to divorce and legal separ ation', COM(2010) 105 final, 24 March, Brussels: European Commission, available at http://eur lex.europa.eu/legal content/EN/ALL/?uri=CELEX:52010PC0105 (accessed August 2014).

European Commission (2011a) 'Proposal for a Council Directive on a Common Consolidated Corporate Tax Base (CCCTB)', COM(2011) 121 final, 16 March, Brussels: European Commission, available at http://eur lex.europa.eu/legal content/EN/ALL/?uri=CELEX:52011PC0121 (accessed August 2014).

European Commission (2011b) 'Proposal for a Council Directive on a common system of financial transaction tax and amending Directive 2008/7/EC', COM(2011) 594 final, 28 September, Brussels: European Commission, available at http://eur lex. europa.eu/legal content/EN/ALL/?uri=CELEX:52011PC0594 (accessed August 2014).

European Commission (2012) 'Proposal for a Council decision authorising enhanced

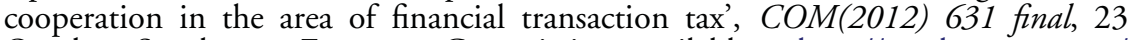
October, Strasbourg: European Commission, available at http://eur lex.europa.eu/ resource.html?uri=cellar:b08e774a 3988 4fba 8cf3 c6a40c4c7f9c.0011.03/DOC 2\&format=PDF (accessed August 2014).

European Commission (2013a) 'Commission staff working document. Impact assess ment. Accompanying the document Proposal for a COUNCIL DIRECTIVE imple menting enhanced cooperation in the area of financial transaction tax. Analysis of policy options and impacts', $S W D(2013) 28$ final, 14 February, Brussels: European Commission, available at http://eur lex.europa.eu/legal content/EN/ALL/?uri= CELEX:52013SC0028 (accessed August 2014).

European Commission (2013b) 'Proposal for a Council Directive implementing enhanced cooperation in the area of financial transaction tax', $\operatorname{COM}(2013) 71$ final, 14 February, Brussels: European Commission, available at http://eur lex. europa.eu/legal content/EN/ALL/?uri=CELEX:52013PC0071 (accessed August 2014).

European Commission (2013c) 'Protecting taxpayer's money against fraud: Commis sion proposes European Public Prosecuto's Office and reinforces OLAF procedural guarantees', Press release IP/13/709, 17 July, Brussels: European Commission, avail able at europa.eu/rapid/press release IP 13709 en.pdf (accessed August 2014).

European Council (2010)'Remarks by Herman van Rompuy, President of the Euro pean Council at the press conference following the meeting of Heads of State or Government', PCE 129/10, 17 June, Brussels: The President of the European Council, available at http://www.consilium.europa.eu/press/press releases/latest press releases/newsroomloaddocument?id=1823\&lang=en \&directory=en/ec $/ \&$ fileName $=115347$.pdf (accessed August 2014).

European Parliament (2001) 'European legislative resolution on the proposal for a Council framework decision on the European arrest warrant and the surrender pro cedures between the Member States', COM(2001) 522 - C5-0453/2001 - 2001/ 0215(CNS), Brussels: European Parliament, available at http://www.europarl. europa.eu/sides/getDoc.do?pubRef=//EP//TEXT+TA+P5 TA 2001 0635+0+DOC+ $\mathrm{XML}+\mathrm{V0} / / \mathrm{EN} \&$ language=EN (accessed August 2014).

European Union (2002) 'Council Framework Decision of 13 June 2002 on the Euro pean arrest warrant and the surrender procedures between Member States', 2002/ 584/JHA, Brussels: Official Journal of the European Communities, avai lable at http://eur lex.europa.eu/legal content/EN/ALL/?uri=CELEX:32002F0584 (accessed August 2014).

European Union (2009) 'Resolution of the Council of 30 November 2009 on a roadmap for strengthening procedural rights of suspected or accused persons in 
criminal proceedings', Resolution 2009/C 295/01, Brussels: Official Journal of the European Union C 295/1, available at http://eur lex.europa.eu/legal content/EN/ TXT/PDF/?uri=OJ:C:2009:295:FULL\&from=EN (accessed August 2014).

European Union (2010) 'Directive 2010/64/EU of the European Parliament and of the Council of 20 October 2010 on the right to interpretation and translation in crim inal proceedings', Brussels: Official Journal of the European Union L 280/1, avail able at http://eur lex.europa.eu/legal content/EN/TXT/?qid=1409317755892\& uri=CELEX:32010L0064 (accessed August 2014).

European Union (2012) 'Directive 2012/13/EU of the European Parliament and of the Council of 22 May 2012 on the right to information in criminal proceedings', Brussels: Official Journal of the European Union L 142/1, available at http://eur lex.europa.eu/ legal content/EN/TXT/?qid=1409317755892\&uri=CELEX:32012L0013 (accessed August 2014).

European Union (2013) 'Directive 2013/48/EU of the European Parliament and of the Council of 22 October 2013 on the right of access to a lawyer in criminal proceed ings and in European arrest warrant proceedings, and on the right to have a third party informed upon deprivation of liberty and to communicate with third persons and with consular authorities while deprived of liberty', Brussels: Offical Journal of the European Union L 294/1, available at http://eur lex.europa.eu/ legal content/EN/TXT/?qid=1409317755892\&uri=CELEX:32013L0048 (accessed August 2014).

Fiorini, A. (2008) 'Rome III choice of law in divorce: is the Europeanization of family law going too far?', International Journal of Law, Policy and the Family 22: 178205.

Friedrichs, J. (2006) 'When push comes to shove: the territorial monopoly of force and the travails of neomedieval Europe', in M. Burgess and H. Vollaard (eds), State Territoriality and European Integration, New York: Routledge, pp. 22851.

Genschel, P. and Plümper, T. (1997) 'Regulatory competition and international co operation', Journal of European Public Policy 4: 62652.

Goertz, G. (2006) Social Science Concepts. A User's Guide, Princeton, NJ: Princeton Uni versity Press.

Gold, M. and Schwimbersky, S. (2008) 'The European company statute: implications for industrial relations in the European Union', European Journal of International Relations 14: $46 \quad 64$

Gomes De Andrade, N.N. (2005) 'Enhanced cooperation: the ultimate challenge of managing diversity in Europe', Intereconomics 40: 20116.

Grahl, J. and Lysandrou, P. (2014) 'The European Commission's proposal for a finan cial transactions tax: a critical assessment', Journal of Common Market Studies 52: 23449 .

Guellec, D. and Van Pottelsberghe De La Potterie, B. (2007) The Economics of the European Patent System. IP Policy for Innovation and Competition, Oxford: Oxford Uni versity Press.

Hamran, L. and Szabova, E. (2013) 'European Public Prosecutor's Office cui bono?', New Journal of European Criminal Law 4: 4058.

Hanf, D. (2001) 'Flexibility clauses in the founding treaties, from Rome to Nice', in B. De Witte, D. Hanf and E. Vos (eds), The Many Faces of Differentiation in EU Law, Antwerp: Intersentia, pp. 326.

Heinrich, M. (2013) 'Steuer(n) in die richtige Richtung? Betrachtungen zur Finanztran saktionssteuer', Wirtschaftsdienst 93: 23842.

Henderson, T. (2010) 'From Brussels to Rome: the necessity of resolving divorce law conflicts across the European Union', Wisconsin International Law Journal 28: 76894.

Holzinger, K. (2005) 'Tax competition and tax co operation in the EU: the case of savings taxation', Rationality and Society 17: 475510. 
Holzinger, K. and Schimmelfennig, F. (2012) 'Differentiated integration in the Euro pean Union: many concepts, sparse theory, few data', Journal of European Public Policy 19: 292305.

Jaeger, T. (2002) 'Enhanced cooperation in the Treaty of Nice and flexibility in the Common Foreign and Security Policy', European Foreign Affairs Review 7: 297316.

Jimeno Bulnes, M. (2008) 'The proposal for a Council framework decision on certain procedural rights in criminal proceedings throughout the European Union', in E. Guild and F. Geyer (eds), Security versus Justice? Police and Judicial Cooperation in the European Union, Aldershot: Ashgate, pp. 171202.

Kaunert, C. (2007) "“Without the power of purse or sword": the European arrest warrant and the role of the Commission', Journal of European Integration 29: 387404.

Keller, B. (2002) 'The European company statute: employee involvement and beyond', Industrial Relations Journal 33: 42445.

Kietz, D. and Maurer, A. 2006. 'Von Schengen nach Prüm. Sogwirkungen verstärkter Kooperation und Anzeichen der Fragmentierung in der EU.', Discussion Paper, Berlin: Stiftung für Wissenschaft und Politik.

Klip, A. (2012) 'The substantive criminal law jurisdiction of the European Public Pro secutor's Office', European Journal of Crime, Criminal Law \& Criminal Justice 20: 36776

Kölliker, A. (2001) 'Bringing together or driving apart the union? Towards a theory of differentiated integration', West European Politics 24: 12551.

Král, D. 2008. Multi-speed Europe and the Lisbon Treaty threat or opportunity?, Prague: EUROPEUM Institute for European Policy.

Kuipers, J. J. (2012) 'The law applicable to divorce as test ground for enhanced cooperation', European Law Journal 18: 20129.

Leuffen, D., Rittberger, B. and Schimmelfennig, F. (2013) Differentiated Integration. Explaining Variation in the European Union, Basingstoke: Palgrave.

Lewis, J. (2010) 'How institutional environments facilitate co operative negotiation styles in EU decision making', Journal of European Public Policy 17: 64864.

Lowi, T.J. (1972) 'Four systems of policy, politics, and choice', Public Administration Review 32: 298310.

Marin, L. (2008) 'The European arrest warrant in the Italian Republic', European Constitutional Law Review 4: 25173.

Mattli, W. (1999) The Logic of Regional Integration. Europe and Beyond, Cambridge: Cambridge University Press.

Mccullock, N. and Pacillo, G. (2011) 'The Tobin Tax: a review of the evidence', Research Report, Brighton: Institute of Development Studies.

Occhipinti, J. D. (2003) The Politics of EU Police Cooperation. Towards a European FBI?, London: Lynne Rienner.

Olson, M. (1965) The Logic of Collective Action. Public Goods and the Theory of Goods, Cambridge, MA: Harvard University Press.

Peers, S. (2010) 'Divorce, European style: the first authorization of enhanced cooperation', European Constitutional Law Review 6: 33958.

Philippart, E. and Edwards, G. (1999) 'The provisions on closer co operation in the Treaty of Amsterdam: the politics of flexibility in the European Union', Journal of Common Market Studies 37: 87108.

Rogoff, K. (2011) 'The wrong tax for Europe', Project syndicate: the world's opinion page, available online at http://www.project syndicate.org/commentary/the wrong tax for europe (accessed 14 November 2013).

Schratzenstaller, M. (2007) 'Corporate taxes in the European Union', Intereconomics 42: 11642.

Sepos, A. 2005. 'Differentiated integration in the EU: the position of small member states', Working Papers RSCAS No. 2005/17, Florence: European University Institute. 
Spronken, T. and De Vocht, D. (2011) 'EU policy to guarantee procedural rights in criminal proceedings: "step by step"', Paper presented at The Future of the Adver sarial System, University of North Carolina at Chapel Hill School of Law, 1 April. Tsebelis, G. (2002) Veto Players, Princeton, NJ: Princeton University Press.

Wade, M.L. (2013) 'A European public prosecutor: potential and pitfalls', Crime Law and Social Change 59: 439 86.

Wagner, W. (2011) 'Negative and positive integration in EU criminal law co oper ation', European Integration Online Papers (EloP) 15, available at http://eiop.or.at/ eiop/index.php/eiop/article/view/2011 003a (accessed August 2014).

Walsch, C. (2008) 'Europeanization and democracy: negotiating the Prüm Treaty and the Schengen III Agreement', Politicka misao XLV: 8190.

White, S. (2013) 'Towards a decentralised European Public Prosecutor's Office', New Journal of European Criminal Law 4(1 2): 2239.

Willan, P. (2001) 'Berlusconi urged to support Europe wide arrest warrant', The Guardian, 9 December, available at http://www.theguardian.com/world/2001/dec/09/ terrorism.humanrights (accessed August 2014). 